\title{
Antidiabetic effect of aqueous stem bark extract of Parinari macrophylla in alloxan- induced diabetic Wistar rats
}

\author{
Ahmad Alhassan Ibrahim ${ }^{1 *}$ D, Muhammed Sani Abdussalami ${ }^{2}$, Joseph Appah², Abdullahi Hussein Umar ${ }^{3}$, \\ Aminu Alhassan Ibrahim ${ }^{4}$ and Kabiru Dawaki Dauda ${ }^{5}$
}

\begin{abstract}
Background: Diabetes is a major public health problem with increasing prevalence globally. Plant-based medicines for diabetes are gaining popularity across the world due to perceptions of efficacy, safety and cost-effectiveness. The plant, Parinari macrophylla, has been widely reported to possess potent ethnomedicinal properties especially in the northern part of Nigeria. However, there has been no scientific documentation of this plant to be used as an antidiabetic agent. The objective of this study was to investigate the antidiabetic effect of aqueous stem bark extract of $P$. macrophylla in alloxan-induced diabetic Wistar rats. Phytochemical screening and acute toxicity studies were conducted. Wistar rats weighing between 100 and $150 \mathrm{~g}$ were used for the study and diabetes was induced using alloxan monohydrate $(150 \mathrm{mg} / \mathrm{kg})$ intraperitoneally. The animals were treated with different doses of aqueous stem bark extract of P. macrophylla (1000 mg/kg and $2000 \mathrm{mg} / \mathrm{kg})$ for 2 weeks. Blood glucose levels and body weight were then monitored. Histopathological investigation of pancreatic tissue was also conducted.

Results: The phytochemical analysis revealed the presence of alkaloids, saponins, tannins, cardiac glycosides, carbohydrates, steroids, and triterpenes as secondary metabolites. The acute toxicity test revealed no mortality with a median lethal dose determined to be above $5000 \mathrm{mg} / \mathrm{kg}$. Although the two different doses of aqueous stem bark extract of $P$. macrophylla decreased blood glucose levels at weeks 1 and 2 , a statistically significant difference $(P<$ 0.05) was only observed for the group treated with $2000 \mathrm{mg} / \mathrm{kg}$ dose compared to the diabetic control group at week 2 . The histological investigation revealed that the two different doses of aqueous stem bark extract of $P$. macrophylla caused regeneration of pancreatic islet cells, with the $2000 \mathrm{mg} / \mathrm{kg}$ dose being more evident.
\end{abstract}

Conclusion: This study suggests that the stem bark extract of $P$. macrophylla possesses a potent antidiabetic effect and may potentially be used to treat diabetes and associated complications.

Keywords: Antidiabetic effect, Alloxan, Blood glucose levels, Pancreatic islet cells, Parinari macrophylla

\section{Background}

Diabetes is a major public health problem with increasing prevalence globally. Current estimates suggest that around 463 million adults in the world are suffering from diabetes and the figure is expected to escalate to 578 million by 2030 and 700 million by 2045 [1]. It is

\footnotetext{
* Correspondence: aaibrahim.cpt@abcoad.edu.ng

'Department of Crop Production Technology, Audu Bako College of

Agriculture Dambatta, Dambatta, Kano State, Nigeria

Full list of author information is available at the end of the article
}

considered to be one of the major causes of morbidity and mortality in both developed and developing countries. However, the prevalence of diabetes in low- and middle-income countries has been rising more rapidly compared to high-income countries. The impact is particularly more devastating in sub-Saharan Africa primarily due to lack of adequate funding for noncommunicable diseases, lack of availability of studies and guidelines specific to the population, and lack of availability of medications to mention but a few [2]. About 
20 million adults aged 20-79 years are living with diabetes in sub-Saharan Africa, with about $60 \%$ of these undiagnosed. This figure is projected to increase to 28.6 million by 2030 and 47.1 million by 2045 [1]. The prevalence of diabetes In Nigeria was reported to be around $5.77 \%$, with about 11.2 million people living with the disease [3].

Diabetes is a metabolic disorder primarily characterized by chronic hyperglycemia with disturbances of carbohydrate, fat and protein metabolism as a result of defects in insulin secretion, insulin action, or both [4]. The most common type of diabetes is type II or insulinindependent diabetes and accounts for about $90-95 \%$ of all cases. Although type I or insulin-dependent diabetes is commonly seen in children, it may also occur in adults [5]. Most diabetes-related complications are due to high levels of glucose in the blood (hyperglycemia). The impact of persistent hyperglycemia in diabetes includes long-term damage, dysfunction, and failure of various organs, especially the eyes, heart, kidneys, nerves, and blood vessels [6]. Thus, diabetes is a complex chronic disorder necessitating continuous medical care with multifactorial risk-reduction strategies beyond glycemic control [7].

The current management of diabetes includes diet, exercise, insulin injection, and oral glucose-lowering drugs [8]. However, synthetic medications are known to be associated with high cost and unpleasant side effects [911 ] and besides cannot cure diabetes since the oral medicines used are not capable of restoring normal glucose homeostasis or controlling all the pathological aspects of the disease [12]. Conversely, plant-based medicines for diabetes are gaining popularity across the world due to perceptions of efficasy, safety and cost-effectiveness [13]. In fact, traditional medicinal practitioners (herbalists) from different parts of the world claim to cure diabetes or at best reduce its major symptoms and progression through the administration of plant-based medicines [12]. In view of the foregoing, alternative treatments to contemporary pharmacotherapy of diabetes are highly needed especially in low-resource income settings where a number of patients cannot afford orthodox therapies.

Several varieties of medicinal plant species have been used traditionally to manage diabetes and many other ailments. There have been more than 400 medicinal plant species reported in the literature to possess antidiabetic properties even though only a few have been proven scientifically as effective antidiabetic agents [14, 15]. In Nigeria, many plant species have been documented to possess potent antidiabetic properties [1618], thus are of significant importance in tackling diabetes in this context. One plant believed to possess potent ethnomedicinal properties is Parinari macrophylla (Sabine) also known as Neocarya macrophylla, which belongs to the family Chrysobalanceae. This plant is found abundantly in the tropical regions of Africa. The plant has been used extensively in the northern part of Nigeria for treating numerous diseases including asthma, dysentery, inflammations, pulmonary troubles, skin infections, eye and ear infections, and wounds [19]. Previous phytochemical screening of $P$. macrophylla plant $[19,20]$ suggests the presence of various secondary metabolites including carbohydrates, alkaloids, flavonoids, anthraquinones, saponins, tannins, glycosides, steroids, and triterpenes all of which may account for the potent pharmacological activities of the plant.

Although P. macrophylla has been reported to possess potent ethnomedicinal properties [19-21], there is no available scientific documentation of this plant to be used as an antidiabetic agent despite many testimonies by traditional medicinal practitioners for using it in the treatment of human diabetes (local communication). Thus, it is imperative to explore the scientific evidence of using this plant for potential safe consumption as an antidiabetic agent in humans as it was earlier claimed. This study, therefore, aimed at investigating the antidiabetic effect of aqueous stem bark extract of P. macrophylla in alloxan-induced diabetic Wistar rats. The plant may provide safe, cheap and effective treatment for patients suffering from diabetes especially in low-resource settings like rural Nigeria.

\section{Methods}

\section{Plant material}

The fresh stem bark of $P$. macrophylla was collected from Kufena village, Zaria, Kaduna State, Nigeria. Botanical authentication of the plant parts was carried out at the herbarium unit of Biological Sciences Department, Ahmadu Bello University, Zaria, Kaduna State, Nigeria. It was identified with a voucher specimen no.: 012341 and deposited at the herbarium unit.

\section{Preparation of plant extracts}

The fresh stem bark of P. macrophylla was air-dried and made into powder using pestle and mortar. The airdried powdered plants $(800 \mathrm{~g})$ materials were extracted with water using soxhlets apparatus. The solvent was removed by vacuum evaporation using a rotary evaporator. A dark brown residue weighing $63.9 \mathrm{~g}$ was obtained and kept in a sealed container and stored in a refrigerator at about $4{ }^{\circ} \mathrm{C}$ until use.

\section{Experimental animals}

Thirty-two apparently healthy male Wistar strain albino rats (8-10 weeks old) weighing 100-150 g were obtained from Animal House, Department of Pharmacology and Clinical Pharmacy, Faculty of Pharmaceutical Sciences, Ahmadu Bello University, Zaria, Kaduna. The animals 
were kept in well-aerated laboratory cages and were allowed to adjust to the laboratory conditions for a period of 2 weeks before the commencement of the experiment. They were fed with grower and starter mash from Vital Feeds Company and water was provided ad libitum during the stabilization period. The principles governing the use and care of laboratory animals, and the experimental protocol were strictly followed in accordance with the National Research Council, Guide on the Care and Use of Laboratory Animals [22]. The study was approved by the Research Ethics Committee of Nigerian Defence Academy, Kaduna, Kaduna State, Nigeria (Ref: NDA/PGS/FS/M/1826/14).

\section{Phytochemical screening}

The preliminary phytochemical screening of the crude extracts of P. macrophylla was conducted at Pharmacognosy Department, Faculty of Pharmaceutical Sciences, Ahmadu Bello University, Zaria, Kaduna to ascertain the presence of their constituents by utilizing standard conventional protocols [23]. The extracts were screened for alkaloids using Mayer's test and Wagner's test, saponins using Frothing test, tannins using Ferichloride test, anthracene derivatives using Bontrager's test, cardiac glycosides using Keller-Killiani test and $\mathrm{NaOH}$ test, flavonoids using Shinoda test and $\mathrm{NaOH}$ test, carbohydrates using Mollish test, and steroids and triterpenes using Liebermann-Burchard test. These tests were carried following the standard protocols reported in the literature [24-26].

\section{Acute toxicity studies}

The median lethal dose $\left(\mathrm{LD}_{50}\right)$ of the plant extract was determined by the modified method of Lorke [27] using 12 rats. In the first phase, rats were divided into 3 groups (3 rats per group) and were treated with the extract at doses of 10,100 , and $1000 \mathrm{mg} / \mathrm{kg}$ body weight orally. They were observed for $24 \mathrm{~h}$ for signs of toxicity. In the second phase, 3 rats were divided into 3 groups ( 1 rat per group) and were also treated with the same extract but at doses of 1600, 2900, and $5000 \mathrm{mg} / \mathrm{kg}$ body weight orally. The median lethal dose $\left(\mathrm{LD}_{50}\right)$ was obtained using the second phase.

\section{Induction of experimental diabetes mellitus}

Twenty rats were used for the experiment. The rats fasted for $24 \mathrm{~h}$ but they were allowed water ad libitum. Diabetes was induced in 15 of the 20 rats using a single intra-peritoneal injection of alloxan monohydrate at the dose of $150 \mathrm{mg} / \mathrm{kg}$ [28]. Because alloxan has the potential to produce fatal, hypoglycemia as a result of massive pancreatic release of insulin, the rats were kept for the next $24 \mathrm{~h}$ on $5 \%$ glucose solution bottles in their cages to prevent hypoglycemia [29]. After $72 \mathrm{~h}$ of alloxan administration, the blood glucose levels (BGLs) of the rats were determined. The rats with BGL $>200 \mathrm{mg} / \mathrm{dl}$ were considered diabetic [30]. The body weight of the animals was monitored daily for 2 weeks.

\section{Experimental design}

The diabetic rats were randomly divided into three groups $(\mathrm{B}-\mathrm{D})$ comprising five rats per group $(n=5)$. Diabetes was not induced in group A, which represents the normal control group, but received $10 \mathrm{ml} / \mathrm{kg}$ of sterile distilled water orally. Group B which represents the diabetic control group received a standard oral hypoglycemic agent: $10 \mathrm{mg} / \mathrm{kg}$ of glibenclamide. Groups $\mathrm{C}$ and D (experimental groups) received oral dose of $1000 \mathrm{mg} / \mathrm{kg}$ and $2000 \mathrm{mg} / \mathrm{kg}$ body weight of aqueous stem bark extract of $P$. macrophylla respectively. All treatments were administered on daily basis for 2 weeks.

\section{Determination of blood glucose levels}

All blood samples were collected from the tail vein of the rats. BGL was determined at an interval of week $0(0$ day), week 1 ( 7 th day), and week 2 (14th day). The determination of the BGLs was done by the glucoseoxidase method [31] using the digital glucometer (AccuCheck advantage, Roche Diagnostic, Germany), and results were reported in $\mathrm{mg} / \mathrm{dl}$.

\section{Histological investigation of the pancreas}

The animals in the normal control and the two experimental groups were sacrificed after the 2 weeks of treatment using chloroform inhalation as anesthesia. The rats were individually placed in an airtight plastic box containing drops of chloroform (37\%) in cotton wool until they become unconscious (maximum time: 2 minutes). An incision was made in the abdomen and sections of their pancreatic tissue were removed and processed for histological examinations at the Gross Anatomy Research Laboratory, Department of Human Anatomy, Faculty of Medical Sciences, Ahmadu Bello University, Zaria, Kaduna State.

\section{Statistical analysis}

Data collected were summarized using descriptive statistics of mean and standard error of measurement (mean \pm SEM). One-way analysis of variance (ANOVA) was used to assess difference between the groups in BGLs and body weight. Where ANOVA showed a significant difference, a post-hoc test with Turkey HSD was applied for multiple pairwise comparisons. All statistical analyses were performed using SPSS version 23.0 (IBM Co., Armonk, NY, USA) with the level of significance set at $P<0.05$. 


\section{Results}

\section{Phytochemical constituents}

The phytochemical screening showed the presence of alkaloids, saponins, tannins, cardiac glycosides, carbohydrates, steroids, and triterpenes in the aqueous stem bark extract of P. macrophylla. However, anthraquinones and flavonoids were not detected in the plant's extract. The results of the phytochemical screening of the aqueous stem bark extract of $P$. macrophylla are presented in Table 1.

\section{Acute toxicity studies}

The results of the acute toxicity test revealed no mortality in the first and the second phase; hence, the $\mathrm{LD}_{50}$ was determined to be above $5000 \mathrm{mg} / \mathrm{kg}$.

\section{Effect of aqueous stem bark extract of $P$. macrophylla on body weight}

Table 2 shows an increase in body weight in all the groups across the weeks except for the groups treated with $1000 \mathrm{mg} / \mathrm{kg}$ and $2000 \mathrm{mg} / \mathrm{kg}$ of aqueous stem bark extract of $P$. macrophylla at week 1 . However, there was no significant difference $(P>0.05)$ in body weight between the groups across the weeks.

\section{Effect of aqueous stem bark extract of $P$. macrophylla on blood glucose levels}

The effect of aqueous stem bark extract of $P$. macrophylla on weekly change in BGLs in the alloxan-induced diabetic Wistar rats is presented in Table 3. The diabetic control group and the groups treated with $1000 \mathrm{mg} / \mathrm{kg}$ and $2000 \mathrm{mg} / \mathrm{kg}$ of aqueous stem bark extract of $P$. macrophylla had a significantly greater increase $(P<$ 0.05 ) in BGLs at week 0 compared to the normal control group. Although the two different doses of aqueous stem bark extract of $P$. macrophylla exhibited hypoglycemic activity in a dose-dependent manner, the group treated with $1000 \mathrm{mg} / \mathrm{kg}$ dose did not significantly reduce BGLs

Table 1 Phytochemical screening of aqueous stem bark extract of P. macrophylla

\begin{tabular}{ll}
\hline Phytochemicals & Presence of phytochemicals \\
\hline Alkaloids & + \\
Saponins & + \\
Tannins & + \\
Anthraquinones & - \\
Cardiac glycosides & + \\
Flavonoids & - \\
Carbohydrates & + \\
Steroids & + \\
Triterpenes & +
\end{tabular}

Key: +ve represents the presence of phytochemicals, -ve represents the absence of phytochemicals at week 1 and $2(P>0.05)$ compared to the diabetic control group and the group treated with $2000 \mathrm{mg} / \mathrm{kg}$. Similarly, the group treated with the $2000 \mathrm{mg} / \mathrm{kg}$ of aqueous stem bark extract of $P$. macrophylla did not significantly reduce BGLs at week $1(P>0.05)$ but at week $2(P<$ $0.05)$ compared to the diabetic control group. Also, the diabetic control group had a significantly greater increase $(P<0.05)$ in BGLs compared to the normal control group at weeks 0 and 1 (Table 3 ).

\section{Pancreatic histology}

The histology study of the pancreatic islet cells of the normal control, $1000 \mathrm{mg} / \mathrm{kg}$ and $2000 \mathrm{mg} / \mathrm{kg}$ groups is shown in Figs. 1, 2 and 3, respectively.

In the normal control group, the histology shows a normal pancreatic structure which was uniform throughout. The islets were full of centrally placed beta cells, appeared very compact, and surrounded by seroacinar cells. The nuclei capillaries were also normal. These findings indicate that the pancreatic islets cells are normal with no sign of atrophy (Fig. 1).

In the group treated with $1000 \mathrm{mg} / \mathrm{kg}$ of aqueous stem bark extract of $P$. macrophylla, the histology shows a slight restoration of the pancreatic islet cells. The nuclei of centrally placed cells were normally stained with hematoxylin and eosin (Fig. 2).

In the group treated with $2000 \mathrm{mg} / \mathrm{kg}$ of aqueous stem bark extract of $P$. macrophylla, the histology shows a moderate restoration of the pancreatic islet cells. There was no manifestation of inflammation. The nuclei of the centrally placed cells were normally stained with hematoxylin and eosin. No infiltrative changes were observed (Fig. 3).

\section{Discussion}

With the rising prevalence of diabetes in developing countries and the adverse effects associated with commonly used allopathic drugs such as biguanides and sulfonylureas, the use of herbal diabetic preparations as alternative treatment has therefore been gaining much attention among many scientists. This study is the first to explore the antidiabetic effect of aqueous stem bark extract of $P$. macrophylla in alloxan-induced diabetic Wistar rats. The results suggest that the plant stem bark extract possesses a potent antidiabetic effect, which may be used in the management of diabetes.

In this study, the phytochemical screening of the aqueous stem bark extract of $P$. macrophylla indicates the presence of alkaloids, saponins, tannins, cardiac glycosides, carbohydrates, steroids, and triterpenes but anthraquinones and flavonoids. The presence of these secondary metabolites in this plant may be attributed to the potent antidiabetic activity observed in the diabetic Wistar rats. In the study by Yusuf and colleagues [19] to 
Table 2 Effect of aqueous stem bark extract of P. macrophylla on body weight in alloxan-induced diabetic Wistar rats

\begin{tabular}{|c|c|c|c|c|c|}
\hline \multirow{2}{*}{$\begin{array}{l}\text { Group } \\
(n= \\
5)\end{array}$} & \multirow[t]{2}{*}{ Treatment given } & \multirow[t]{2}{*}{ Dose } & \multicolumn{3}{|l|}{ Body weight (g) } \\
\hline & & & Week 0 & Week 1 & Week 2 \\
\hline 1 & Normal control (distilled water) & $10 \mathrm{ml} / \mathrm{kg}$ & $118.00 \pm 4.77^{a}$ & $135.02 \pm 3.37^{\mathrm{a}}$ & $147.20 \pm 5.95^{a}$ \\
\hline 2 & Diabetic control (glibenclamide) & $10 \mathrm{mg} / \mathrm{kg}$ & $129.00 \pm 7.59^{\mathrm{a}}$ & $144.00 \pm 9.41^{\mathrm{a}}$ & $147.20 \pm 5.95^{\mathrm{a}}$ \\
\hline 3 & PMAE & $1000 \mathrm{mg} / \mathrm{kg}$ & $138.00 \pm 15.36^{\mathrm{a}}$ & $137.00 \pm 11.93^{\mathrm{a}}$ & $145.50 \pm 11.89^{a}$ \\
\hline 4 & PMAE & $2000 \mathrm{mg} / \mathrm{kg}$ & $140.50 \pm 11.75^{\mathrm{a}}$ & $137.50 \pm 11.58^{\mathrm{a}}$ & $143.00 \pm 8.26^{a}$ \\
\hline
\end{tabular}

Values are presented in mean \pm SEM; PMAE Parinari macrophylla aqueous stem bark extract; values in the same column having different letters of alphabets are statistically significant $(P<0.05)$

explore the phytochemical composition and antimicrobial properties of the methanol stem bark extract of $P$. macrophylla, the presence of alkaloids, saponins, tannins, cardiac glycosides, carbohydrates, steroids, triterpenes, anthraquinones, and flavonoids were revealed as the secondary metabolites similar to the findings of the current study except for the absence of anthraquinones and flavonoids. Additionally, in line with our findings, previous studies [32-35] exploring the antidiabetic effects of different plant origins in animal model, also reported the presence of one or more of these promising compounds.

The presence of saponins in the aqueous stem bark extract of $P$. macrophylla is specifically relevant, as these phytochemicals are known to regulate BGLs and prevent diabetic complications owing to their antioxidant activity [36]. Additionally, they are reported to possess a hypocholesterolemic effect which may help to reduce the risk of atherosclerosis and cardiovascular disease in diabetes [37]. Thus, the presence of these metabolites may support the use of $P$. macrophylla plant in diabetes management considering their ability to lessen metabolic burden that would have been placed on the liver [38]. Similarly, tannins such as epigallocatechin-3-gallate have been reported to exhibit hypoglycemic activity [39]. The mechanisms underlining tannin therapeutic activity may include iron deprivation, hydrogen bonding, or specific interactions with vital proteins such as enzymes that bring about their roles as stable and potent antioxidants [40].

Regarding the results of the body weight across the study periods, the treatment with aqueous stem bark extract of P. macrophylla, irrespective of the two different doses, did not result in significant weight gain in the studied animals between week 0 and 1 but a slight increase in body weight was observed between week 1 and 2. However, there was a trend showing an increase in body weight between week 0 and 2 in the control and diabetic control groups. Even though there was no significant difference between the groups, our finding is somewhat comparable to the finding of Gupta and Sharma [40] who reported a significant decrease in body weight of diabetic rats receiving an aqueous extract of some medicinal plants compared to controls. The pattern of body weight changes observed across the groups treated with aqueous stem bark extract of $P$. macrophylla might be due to differences in the dosage administered to each group. However, this was done to ascertain the appropriate dosage required to induce a significant antidiabetic effect. Thus, it can be inferred that the daily oral administration of the aqueous stem bark extract of $P$. macrophylla to the study rats in addition to their regular feeds could be attributed to the changes in body weight observed.

The results of our study demonstrated potent antidiabetic activity of different doses of the aqueous stem bark extract of $P$. macrophylla evidenced by the lower BGLs observed across the weeks. This effect could be attributed to the antioxidant activities of the polyphenolic compounds present in the plant stem bark extract. At week 0 , the groups treated with $1000 \mathrm{mg} / \mathrm{kg}$ and 2000 $\mathrm{mg} / \mathrm{kg}$ had more increase in BGLs compared to the diabetic control group. However, at weeks 1 and 2, the different doses had a decrease in BGLs with the $2000 \mathrm{mg} /$ $\mathrm{kg}$ dose exhibiting a greater reduction in BGLs at week 2

Table 3 Effect of aqueous stem bark extract of P. macrophylla on blood glucose levels in alloxan-induced diabetic Wistar rats

\begin{tabular}{llllll}
\hline $\begin{array}{l}\text { Group } \\
(\boldsymbol{n}=\end{array}$ & Treatment given & Dose & \multicolumn{3}{l}{ Blood glucose levels (mg/dl) } \\
\cline { 4 - 6 } $\mathbf{5}$ & & & Week 0 & Week 1 & Week 2 \\
\hline 1 & Normal control (distilled water) & $10 \mathrm{ml} / \mathrm{kg}$ & $85.40 \pm 0.60^{\mathrm{a}}$ & $88.20 \pm 1.98^{\mathrm{a}}$ & $88.00 \pm 8.00^{\mathrm{a}}$ \\
2 & Diabetic control (glibenclamide) & $10 \mathrm{mg} / \mathrm{kg}$ & $277.25 \pm 60.82^{\mathrm{b}}$ & $179.00 \pm 20.61^{\mathrm{ab}}$ & $188.25 \pm 40.68^{\mathrm{a}}$ \\
3 & PMAE & $1000 \mathrm{mg} / \mathrm{kg}$ & $281.25 \pm 23.17^{\mathrm{b}}$ & $152.25 \pm 6.31^{\mathrm{ac}}$ & $149.75 \pm 6.93^{\mathrm{a}}$ \\
4 & PMAE & $2000 \mathrm{mg} / \mathrm{kg}$ & $250.50 \pm 29.83^{\mathrm{b}}$ & $171.50 \pm 24.36^{\mathrm{b}}$ & $102.25 \pm 6.96^{\mathrm{a}}$ \\
\hline
\end{tabular}

Values are presented in mean \pm SEM; PMAE, Parinari macrophylla aqueous stem bark extract; values in the same column having different letters of alphabets are statistically significant $(p<0.05)$ 


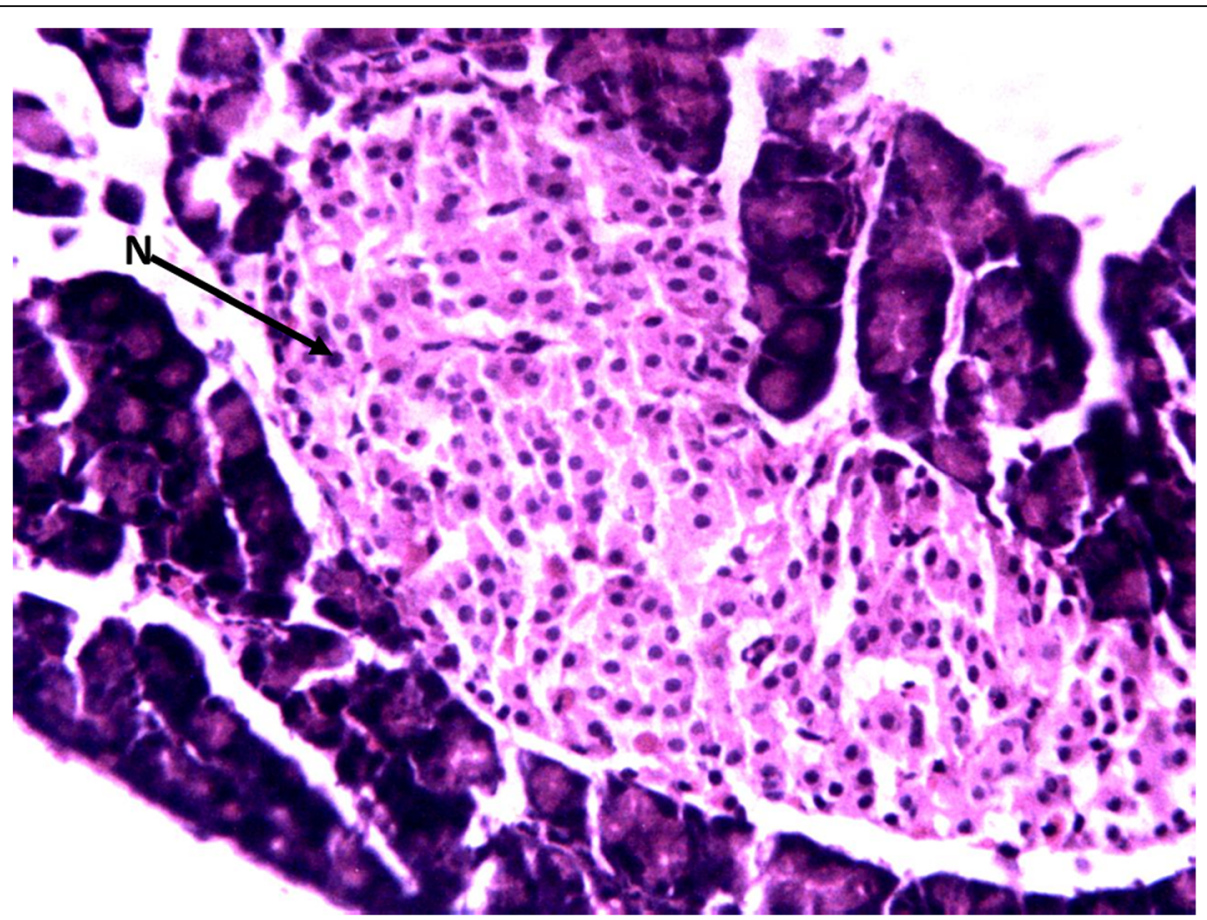

Fig. 1 Histology of the pancreas section stained with hematoxylin and eosin in the normal control group, $\times 250$. N, normal pancreatic islet cells

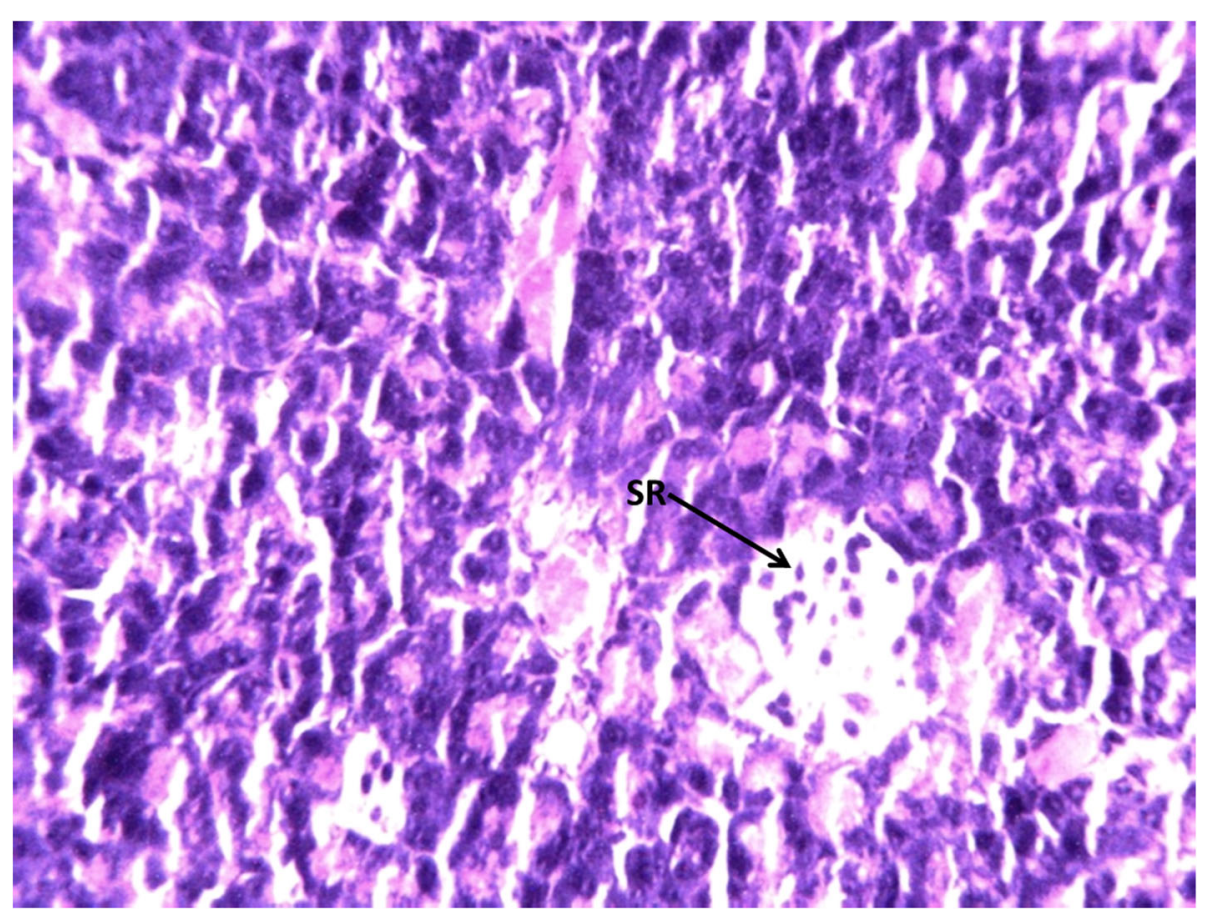

Fig. 2 Histology of the pancreas section stained with hematoxylin and eosin in the group treated with $1000 \mathrm{mg} / \mathrm{kg}$ of aqueous stem bark extract of $P$. macrophylla, $\times 250$. SR, slightly restored pancreatic islet cells 


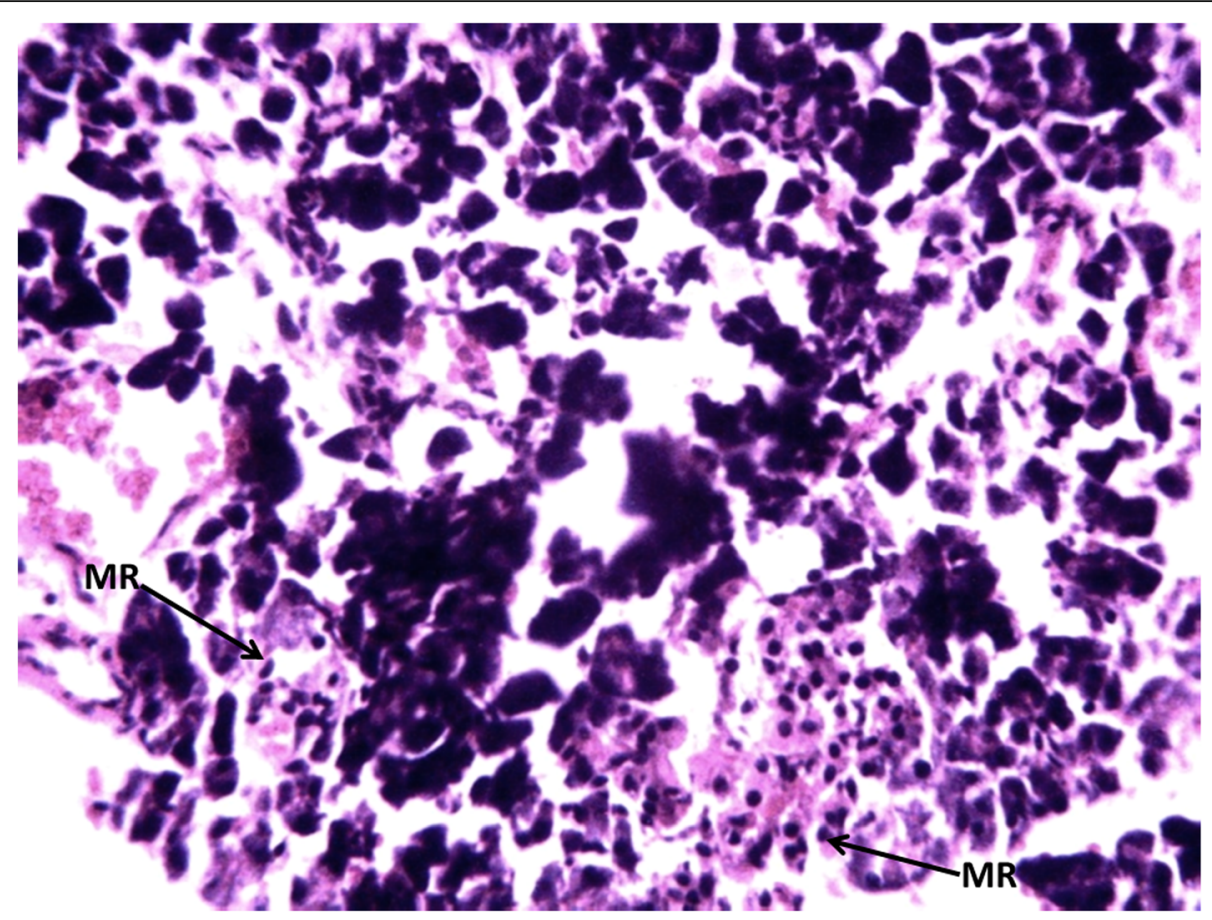

Fig. 3 Histology of the pancreas section stained with hematoxylin and eosin in the group treated with $2000 \mathrm{mg} / \mathrm{kg}$ of aqueous stem bark extract of $P$. macrophylla, $\times 250$. MR, moderately restored pancreatic islet cells

compared to the diabetic control group. By implication, the $2000 \mathrm{mg} / \mathrm{kg}$ dose proved to be more effective in the management of diabetes.

Alloxan is one of the cytotoxic glucose analogs prominently used as diabetogenic agents to induce diabetes in experimental animals. Two distinct mechanisms by which alloxan-induced diabetes involve selective inhibition of glucose-induced insulin secretion through specific inhibition of glucokinase (the glucose sensor of the beta cell), and generation of reactive oxygen species (ROS) which lead to inadequate secretion of insulin or a state of insulin-dependent diabetes, resulting in sequential necrotic beta cells death [41]. The actions of the aqueous stem bark extract of $P$. macrophylla on the BGLs in this study could have been from direct mopping out of the ROS generated from alloxan toxicity thereby restoring a balance between the pro-oxidants and the antioxidants within the system. The activities of the extracts could also have been from upregulation or augmentation of endogenous antioxidants enzymes leading to the mitigation of oxidative stress. Diabetic patients do not only tend to have increased levels of ROS and reactive nitrogen species but also reduced antioxidant defenses [42]. The action of the extracts from this study could also have been from the direct stimulatory activity of these extracts on surrounding pancreatic beta cells, resulting in insulin secretion and subsequent tissue utilization of blood glucose and decreased BGLs.

Histomorphological evaluation of the pancreatic tissue in this study revealed normal islet cells in the pancreas in the normal rats. Alloxan destroyed the islet cells of pancreas as observed in the diabetic Wistar rats relative to the normal control. However, treatment with aqueous stem bark extract of $P$. macrophylla led to the regeneration of pancreatic islet cells. This is more evident in the group treated with the $2000 \mathrm{mg} / \mathrm{kg}$ dose. The restoration of pancreatic islet cells is believed to increase insulin secretion. Accumulation of glucose in tissues could have precipitated into reduction of the glucose to sorbitol and activation of the polyol pathway. These actions could cause subsequent osmosis and apoptosis of the pancreatic cells in hyperglycemic conditions. Treatment with the aqueous stem bark extract of $P$. macrophylla could have interrupted such pathway, stopping the progressive damage of the islet cells and activation of healing mechanisms as shown from the histology. In light of the foregoing, P. macrophylla plant could be considered in the treatment of insulin-dependent diabetic conditions.

\section{Conclusion}

In conclusion, aqueous stem bark extract of $P$. macrophylla was found to possess a potent antidiabetic effect. Moreover, the plant can cause regeneration of pancreatic 
islet cells thereby improving insulin secretion. Based on these findings, $P$. macrophylla plant may potentially be used to treat human diabetes and associated complications. Future studies should be conducted on leaves and roots of this plant to further explore its potential antidiabetic properties. Additionally, exploring hematological and lipidemic activities of aqueous stem bark extract of P. macrophylla in future studies would be useful.

\section{Abbreviations \\ $\mathrm{NaOH}$ : Sodium hydroxide; LD50: Median lethal dose; BGL: Blood glucose level; PMAE: Parinari macrophylla aqueous stem bark extract; SEM: Standard error of measurement; ANOVA: Analysis of variance; ROS: Reactive oxygen species}

\section{Acknowledgments \\ We would like to thank the entire staff of Biological Science Department, Nigerian Defence Academy, Kaduna, Kaduna State, for their cooperation and understanding during the conduct of this study. We also acknowledge the entire staff of Human Physiology Department, Ahmadu Bello University, Zaria, Kaduna State, for allowing us to use their laboratory and equipment. Furthermore, our appreciation goes to Prof. M.D. Mukhtar and late Prof. I.I. Indabawa of Faculty of Life Sciences, Bayero University, Kano, for their valuable input.}

\section{Plant authentication}

Botanical authentication of the plant parts was carried out at the herbarium unit of Biological Sciences Department, Ahmadu Bello University, Zaria, Kaduna State, Nigeria (voucher specimen no.: 012341).

\section{Authors' contributions}

AAI Sr, MSA, and JA conceptualized and design the study. AAI Sr and AHU executed the experiments and analyzed the data. AAI Sr and AAI Jr were responsible for drafting the final manuscript. MSA and JA supervised the study. AAI Jr and KDD were responsible for reviewing the final manuscript. All authors read and approved the final manuscript.

\section{Funding}

This study received no specific grant from any funding agency in the public, commercial, or not-for-profit sectors.

\section{Availability of data and materials}

The data used to support the findings of this study are available from the corresponding author.

\section{Declarations}

\section{Ethics approval and consent to participate}

All animal procedures and experimental protocol were strictly followed as per the National Research Council, Guide for the Care and Use of Laboratory Animals. The study was approved by the Research and Ethical Committee on the use of laboratory animals of Nigerian Defence Academy, Kaduna, Kaduna State, Nigeria (Ref: NDA/PGS/FS/M/1826/14).

\section{Consent for publication}

Not applicable

\section{Competing interests}

All authors declare that they have no competing interests.

\section{Author details}

'Department of Crop Production Technology, Audu Bako College of Agriculture Dambatta, Dambatta, Kano State, Nigeria. ${ }^{2}$ Department of Biological Sciences, Faculty of Science, Nigerian Defence Academy, Kaduna, Kaduna State, Nigeria. ${ }^{3}$ Department of Human Physiology, Faculty of Basic Medical Sciences, Ahmadu Bello University, Zaria, Kaduna State, Nigeria. ${ }^{4}$ Department of Physiotherapy, Muhammad Abdullahi Wase Teaching Hospital, Hospitals Management Board, Kano, Kano State, Nigeria.
${ }^{5}$ Department of Crop Science, Kano University of Science and Technology, Wudil, Kano State, Nigeria.

Received: 2 January 2021 Accepted: 8 July 2021

Published online: 21 August 2021

\section{References}

1. Internation Diabetes Federation (2019) IDF diabetes Atlas Ninth. Dunia IDF

2. Pastakia SD, Pekny CR, Manyara SM, Fischer L (2017) Diabetes in subSaharan Africa-from policy to practice to progress: targeting the existing gaps for future care for diabetes. Diabetes Metab Syndr Obes 10:247-263

3. Uloko AE, Musa BM, Ramalan MA, Gezawa ID, Puepet FH, Uloko AT, Borodo MM, Sada KB (2018) Prevalence and risk factors for diabetes mellitus in Nigeria: a systematic review and meta-analysis. Diabetes Ther 9(3):13071316. https://doi.org/10.1007/s13300-018-0441-1

4. World Health Organization (1999) Definition, diagnosis, and classification of diabetes mellitus and its complications: report of a WHO consultation. World Health Organization, Geneva

5. American Diabetes Association (2010) Diagnosis and classification of diabetes mellitus. Diabetes Care 33(Suppl 1):S62-S69. https://doi.org/10.233 7/dc10-S062

6. Chatterjee S, Davies MJ (2015) Current management of diabetes mellitus and future directions in care. Postgrad Med J 91(1081):612-621. https://doi. org/10.1136/postgradmedj-2014-133200

7. American Diabetes Association (2019) Standards of medical care in diabetes-2019. Diabetes Care 42(Suppl 1):S1-S2

8. Cefalu WT, Dawes DE, Gavlak G, Goldman D, Herman WH, Van Nuys K (2018) Insulin access and affordability working group: conclusions and recommendations. Diabetes Care 41(6):1299-1311. https://doi.org/10.2337/ dci18-0019

9. Moucheraud C, Lenz C, Latkovic M, Wirtz VJ (2019) The costs of diabetes treatment in low- and middle-income countries: a systematic review. BM Glob Health 4(1):e001258. https://doi.org/10.1136/bmjgh-2018-001258

10. Corathers SD, Peavie S, Salehi M (2013) Complications of diabetes therapy. Endocrinol Metab Clin North 42(4):947-970. https://doi.org/10.1016/j.ecl.2 013.06.005

11. Rahmatullah M, Azam MNK, Khatun Z, Seraj S, Islam F, Rahman MA, Jahan S, Aziz MS (2012) Medicinal plants used for treatment of diabetes by the Marakh sect of the Garo tribe living in Mymensingh district, Bangladesh. Afr J Tradit Complement Altern Med 9(3):380-385

12. Chege IN, Okalebo FA, Guantai AN, Karanja S, Derese S (2015) Management of type 2 diabetes mellitus by traditional medicine practitioners in Kenya-key informant interviews. Pan Afr Med J 22:90

13. Chang HY, Wallis M, Tiralongo E (2007) Use of complementary and alternative medicine among people living with diabetes: literature review. J Adv Nurs 58(4):307-319. https://doi.org/10.1111/j.1365-2648.2007.04291.x

14. Modak M, Dixit P, Londhe J, Ghaskadbi S, Devasagayam TP (2007) Indian herbs and herbal drugs used for the treatment of diabetes. J Clin Biochem Nutr 40(3):163-173. https://doi.org/10.3164/jcbn.40.163

15. Iweala EE, Oludare FD (2011) Hypoglycemic effect, biochemical and histological changes of Spondias mombin Linn. and Parinari polyandra Benth. seeds ethanolic extracts in alloxan-induced diabetic rats. J Pharmacol Toxicol 6(2):101-112. https://doi.org/10.3923/jpt.2011.101.112

16. Vongtau HO, Abbah J, Ngazal IE, Kunle OF, Chindo BA, Otsapa PB, Gamaniel KS (2004) Anti-nociceptive and anti-inflammatory activities of the methanolic extract of Parinari polyandra stem bark in rats and mice. $J$ Ethnopharmacol 90(1):115-121. https://doi.org/10.1016/j.jep.2003.09.038

17. Fred-Jaiyesimi AA, Wilkins MR, Abo KA (2009) Hypoglycaemic and amylase inhibitory activities of leaves of Spondias mombin Linn. Afr J Med Med Sci 38(4):343-349

18. Audu O, Oyewale A, Amupitan J (2005) The biological activities of secondary metabolites of Parinari macrophylla Sabine. Chem Class J 2:19-21

19. Yusuf A, Abdullahi M, Haruna A, Musa A, Abdullahi M, Ibrahim Z, Halilu M, Odiba O (2015) Phytochemical and antimicrobial evaluations of the methanol stem bark extract of Neocarya macropylla. J Chem Pharm Res 7(1):477-481

20. Halilu ME, Abah JO, Almustapha NL, Achor M (2010) Phytochemical screening and mineral element analysis of the root bark of Parinari macrophylla Sabine (Chrysobalanaceae) and its effect on microorganisms. Cont J Biol Sci 3:46-50 
21. Hassanshy SW, Verma S, Srivastava SK, Luqman S, Gupta U, Masood N (2013) Activity quided isolation and characterization of antioxidant and antibacterial agents from some local Nigerian plants. Afr J Biotechnol 12(44): 6315-6325

22. National Research Council (2011) Guide for the Care and Use of Laboratory Animals, 8th edn. The National Academies Press, Washington

23. Trease GE, Evans WC (1983) Textbook of pharmacognosy, 12th edn. Tindall and $\mathrm{Co}$, London

24. Gul R, Jan SU, Faridullah S, Sherani S, Jahan N (2017) Preliminary phytochemical screening, quantitative analysis of alkaloids, and antioxidant activity of crude plant extracts from Ephedra intermedia Indigenous to Balochistan. Sci World J 2017:5873648. https://doi.org/10.1155/2017/5873648

25. Debiyi OO, Sofowora FA (1987) Pytochemical screening of medical plants. Iloyidia 3:234-246

26. Sofowora A (1993) Phytochemical screening of medicinal plants and traditional medicine in Africa. Spectrum Books Ltd, Ibadan, Nigeria

27. Lorke D (1983) A new approach to practical acute toxicity testing. Arch Toxicol 54(4):275-287. https://doi.org/10.1007/BF01234480

28. Katsumata K, Katsumata K Jr, Katsumata Y, Ozawa T (1994) Acute and chronic effect of ethanol on the occurrence of alloxan diabetes in rats. Horm Metab Res 26(4):166-168. https://doi.org/10.1055/s-2007-1000803

29. Dhandapani S, Subramanian VR, Rajagopal S, Namasivayam N (2002) Hypolipidemic effect of Cuminum cyminum L. on alloxan-induced diabetic rats. Pharmacol Res 46(3):251-255. https://doi.org/10.1016/S1043-6618(02 )00131-7

30. Stanely Mainzen Prince P, Menon VP (2001) Antioxidant action of Tinospora cordifolia root extract in alloxan diabetic rats. Phytother Res 15(3):213-218. https://doi.org/10.1002/ptr.707

31. Beach EF, Turner JJ (1958) An enzymatic method for glucose determination in the body fluids. J Clin Chem 4(6):462-475. https://doi.org/10.1093/ clinchem/4.6.462

32. Nojima H, Kimura I, F-j C, Sugihara Y, Haruno M, Kato A, Asano N (1998) Antihyperglycemic effects of $\mathrm{N}$-containing sugars from Xanthocercis zambesiaca, Morus bombycis, Aglaonema treubii, and Castanospermum australe in streptozotocin-diabetic mice. J Nat Prod 61(3):397-400. https:// doi.org/10.1021/np9702771

33. Kim HY, Moon BH, Lee HJ, Choi DH (2004) Flavonol glycosides from the leaves of Eucommia ulmoides $\mathrm{O}$. with glycation inhibitory activity. J Ethnopharmacol 93(2-3):227-230. https://doi.org/10.1016/.j.jep.2004.03.047

34. Mohammed A, Adelaiye A, Bakari A, Mabrouk M (2009) Anti-diabetic and some haematological effects of ethylacetate and $n$-butanol fractions of Ganoderma lucidum aqueous extract in alloxan-induced diabetic Wistar rats. Int J Med Med Sci 1(12):530-535

35. Balogun O, Ojerinde SO, Alemika TM (2013) Hypoglycemic effect of the aqueous stem bark extract of Boswellia dalzielii Hutch. Cont J Pharm Sci 7(1):36-41

36. El Barky AR, Hussein SA, Alm-Eldeen A-E (2017) Saponins and their potential role in diabetes mellitus. Diabetes Manag 7(1):148-158

37. Ruhe RC, McDonald RB (2001) Use of antioxidant nutrients in the prevention and treatment of type 2 diabetes. J Am Coll Nutr 20(Suppl 5): S363-S369. https://doi.org/10.1080/07315724.2001.10719169

38. Verma L, Khatri A, Kaushik B, Patil UK, Pawar RS (2010) Antidiabetic activity of Cassia occidentalis (Linn) in normal and alloxan-induced diabetic rats. Indian J Pharm 42(4):224-228. https://doi.org/10.4103/0253-7613.68422

39. Xie JT, Wang A, Mehendale S, Wu J, Aung HH, Dey L, Qiu S, Yuan CS (2003) Anti-diabetic effects of Gymnema yunnanense extract. Pharmacol Res 47(4): 323-329. https://doi.org/10.1016/S1043-6618(02)00322-5

40. Gupta R, Sharma A (2017) Anti-hyperglycemic activity of aqueous extracts of some medicinal plants on Wistar rats. J Diabetes Metab 8(752):2

41. Lenzen S (2008) The mechanisms of alloxan- and streptozotocin-induced diabetes. Diabetologia 51(2):216-226. https://doi.org/10.1007/s00125-0070886-7

42. Bandeira S d M, da Fonseca LJ, Guedes G d S, Rabelo LA, Goulart MO, Vasconcelos SM (2013) Oxidative stress as an underlying contributor in the development of chronic complications in diabetes mellitus. Int J Mol Sci 14(2):3265-3284. https://doi.org/10.3390/ijms14023265

\section{Publisher's Note}

Springer Nature remains neutral with regard to jurisdictional claims in published maps and institutional affiliations.

\section{Submit your manuscript to a SpringerOpen ${ }^{\circ}$ journal and benefit from:}

- Convenient online submission

- Rigorous peer review

- Open access: articles freely available online

- High visibility within the field

- Retaining the copyright to your article

Submit your next manuscript at $\boldsymbol{\nabla}$ springeropen.com 